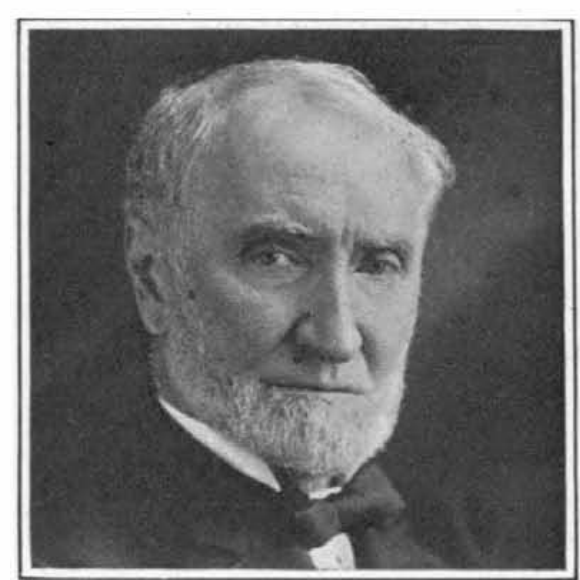

Copyright by Harris and Eming.

1-A conservative, persistent, reserved type A good exampie of hard consistency. (Note severity in expression of face; especially of tue noutb.)

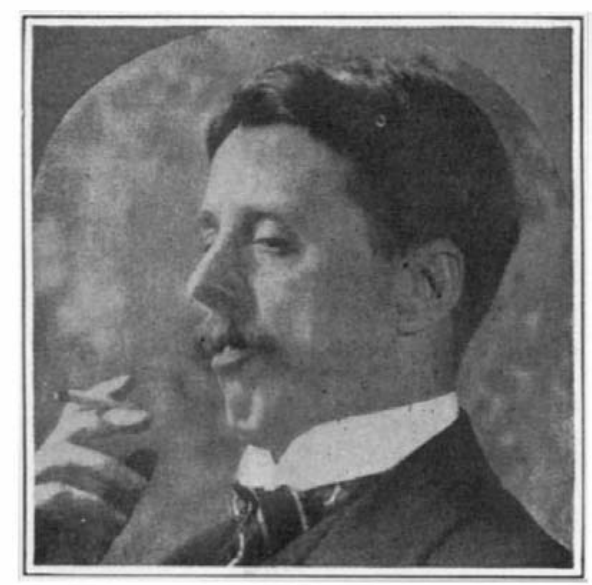

5-Convex type. Artistic in his inclinations and strong in
chiefly in himself.

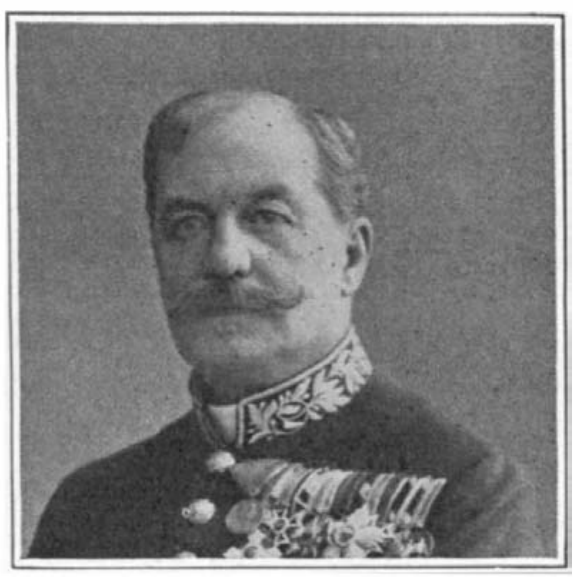

6-A type wbich is patient, persistent, in sistent, tenacious, just and deliberating,

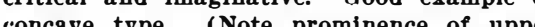
forehead and chin.)

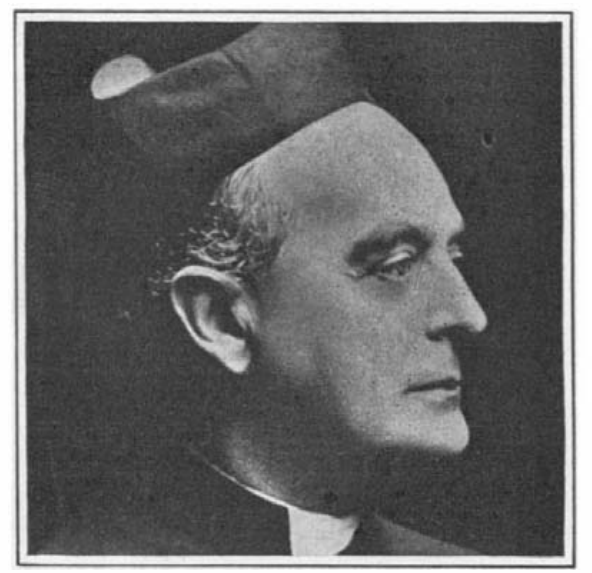

7-Convex upper and concave lower face. A man who is original, a keen observer, ten-
acious, courageous and broad-minded.

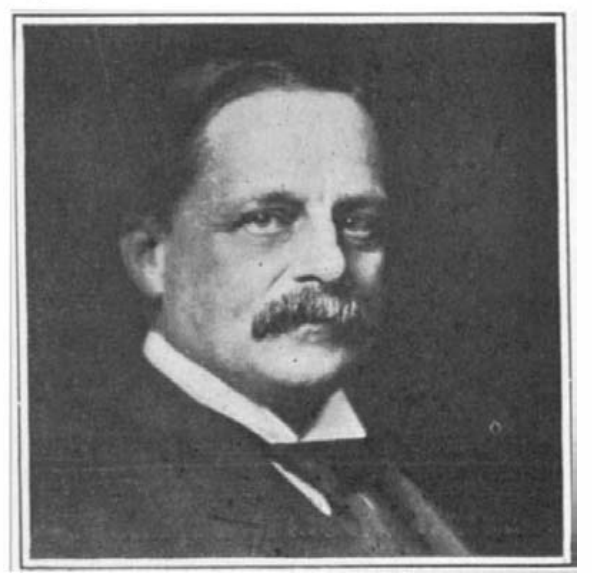

Phow. by Pirie MacDosald

8. A distinguished electrical engineer. A well-balanced type. Persuasive and philusopblcal.

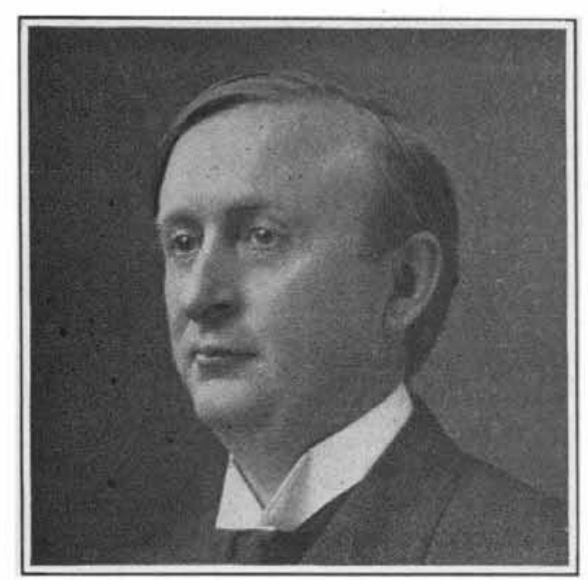

2-Mental-philosophical type of soft-elastic consistency. A sympatbetic, optimistic, re sponsive and emotional man, who would not
barmonize with the type pictured in No. 1 .

\section{The Scientific Employment of Men}

\section{Standardizing Human Character}

\section{By Herbert Newton}

PICK up any daily newspaper published in any large American city and you may read dozens of advertisements worded thus:

$$
\begin{aligned}
& \text { WANTED-Entry clerk in receiving department of } \\
& \text { wbolesale drygoods house. Not over forty. Must } \\
& \text { be conscientious, accurate, and experienced. . Ad- } \\
& \text { dress X. Y. Z., Box 241, The Planet, Uptown Office. }
\end{aligned}
$$

A hundred applicants write. Those whose letters are least ungrammatical are invited to "call and see our Mr. Jackson between nine and ten o'clock to-morrow morning." They duly appear. Mr. Jackson looks his men over. The old ones, the shabby ones, the drowsy looking ones, are promptly dismissed. Mr. Jackson may be right or wrong in disposing of them thus summarily. The rest he questions. Invariably he asks: "What is your experience?" Finally he selects a man not unattractive in appenrance, one who has been in the drygoods business for five years.

Will the man stay in his new place? Will he be acceptable to his fellow workers? Can he be counted upon in an emergency? Will he have the interests of the house at heart? Only time can tell; not Mr. Jackson.

This is the time-honored "hiring and firing" method-wasteful and expensive. But is there anything better? Is there any way of standardizing men a machines and materials are standardized? Is there any way of specifying human characteristics as accurately as belting and steel are specified for a machine shop?

Business men have thus far interested themselves but little in this matter. Theirs are still the hit and miss methods of antiquity. They try a man for a time, which is equivalent to sampling a patent medicine or demonstrating a machine, and they cherish the illusion that they are proceeding in a practical business-like way.

The sales manager of one large firm once tried three hundred candidates before he succeeded in obtaining an even passably efficient force of twenty-five salesmen. The cost of engaging, partially training, and finally weeding out the 275 unfit amounted to over $\$ 90,000$. This was the actual money lost. The waste of time, energy and opportunity for profitable sales can be scarcely estimated.

Business men forget that the demonstration method is expensive and that it may sometimes prove disastrous. Sometimes they try to cast upon another the cost of demonstrating a man's fitness. Hence, it is a common practice to appropriate men who have demonstrated their ability in some enterprise. Where would the American navy be if it attempted to officer its ships by appropriating British, French, and Japanese officers of ability?

Selection on a basis of experience (Mr. Jackson's method) is common, but equally unsatisfactory. Better a pedigreed colt from racing stock than an experienced cart horse if racing is the function required. The truth is that experience without aptitude is worth little; and that aptitude without experience may be worth much. Experience is important, but it is easily acquired when there is aptitude, days or weeks giving a proficiency not otherwise accumulated in months or years. But how can aptitudes be judged? Psychological tests have been advocated, but their application is exceedingly limited. A man is not necessarily a good locomotive engineer because he can distinguish red from green and because he responds quickly to signals. No psychological instrument thus far devised can determine whether he is careful, whether he has presence of mind, whether he is trustworthy.

Ideally, an efficient commercial or industrial organization is correctly designed as to functions and their inter-relation. whether executive or subordinate, is fitted by natural aptitudes, training and experience for his function, and all are associated with reference to their common adaptability and harmonious co-operation. Engineers, executives and organizers have worked on the problem of design until it now approaches the ideal. The chart of organization with line and staff functions devised by Mr. Harrington Emerson and the functional foremanship plan of Mr. Frederick W. Taylor are examples.

It remained for someone to bring the problem of scientific selection and assignment of employees out of chaos and haphazard methods into scientific efficiency. This has been and is being done practically in several large commercial organizations, according to a plan originated and made the basis of employment departments by Dr. Katherine M. H. Blackford.

Dr. Blackford proceeds on the principle that "the largest sums of money, the inest materials, the latest and best equipment, the most cleverly and intelli-

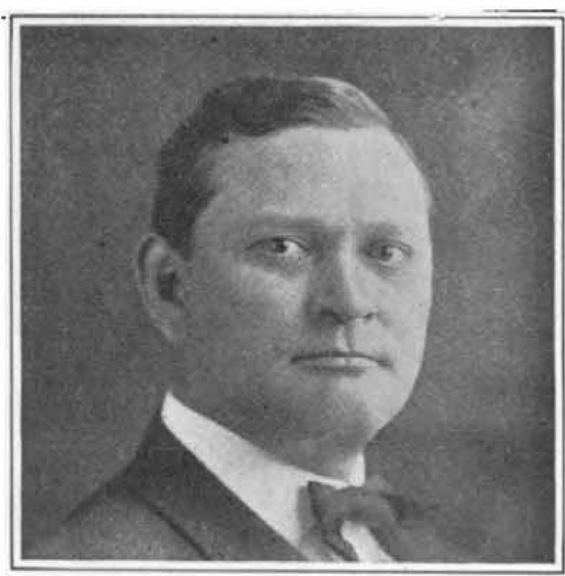

Copyright by Harrio and Ewlog.
4-Another example of the vital type Speculative and aggressive. Very obstinate. A good fnancier. A man not easily influenced.

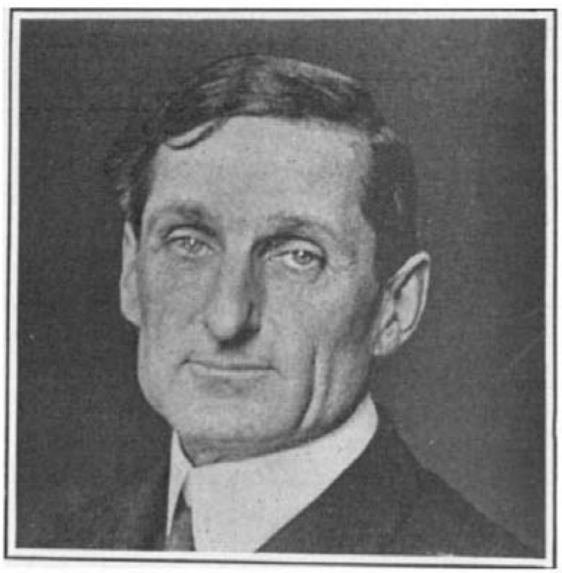

Copyright by Harris and Ewing.

9-Determined. Liberty-loving. A natural pioneer. Tbe motive type. (Not
ness of features with long lines.)

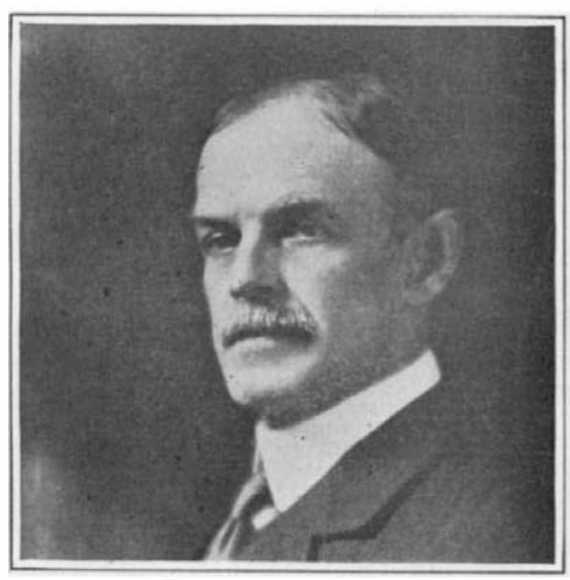

Photo. by Pirie MLe.Deuald.

10-A well-known electrical engineer, a good example of the motive type.

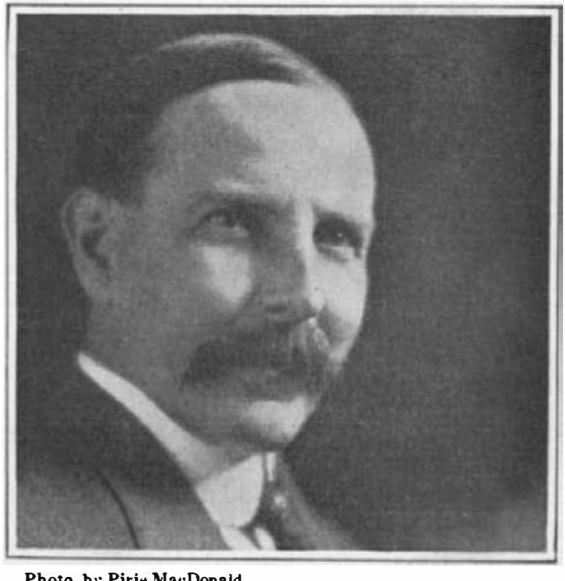

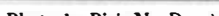

11-A well-known enginecr of the educator type. Affable, tactful, and popular.

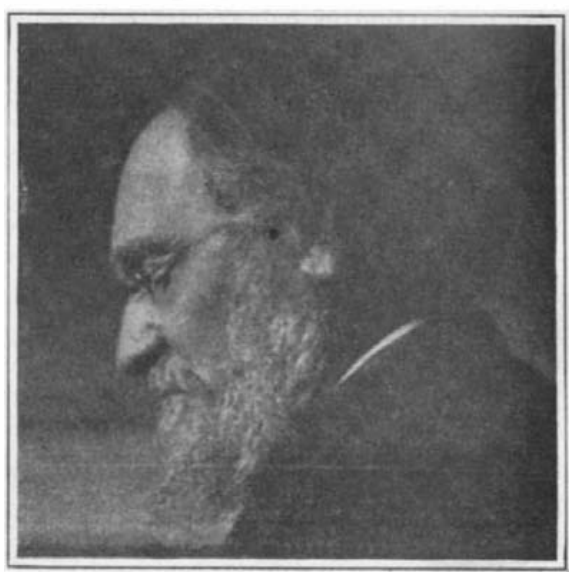

12-A good example of the professional type. A scientist with a passion for facts. (Not 


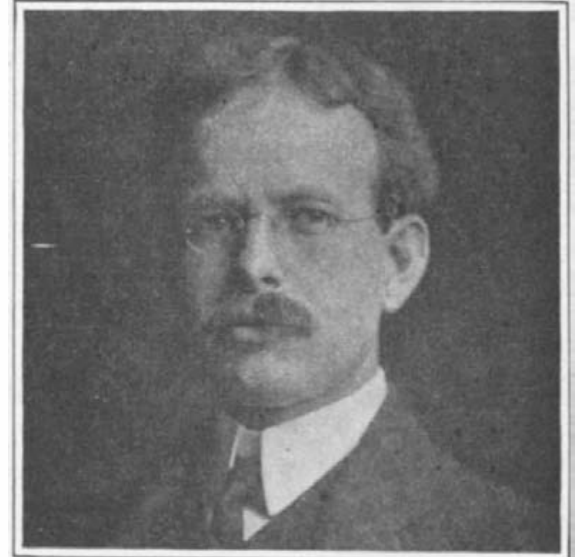

13-Enthusiasm and Idealism, coupled with business ability, are disclosed by this type. He and
monious.

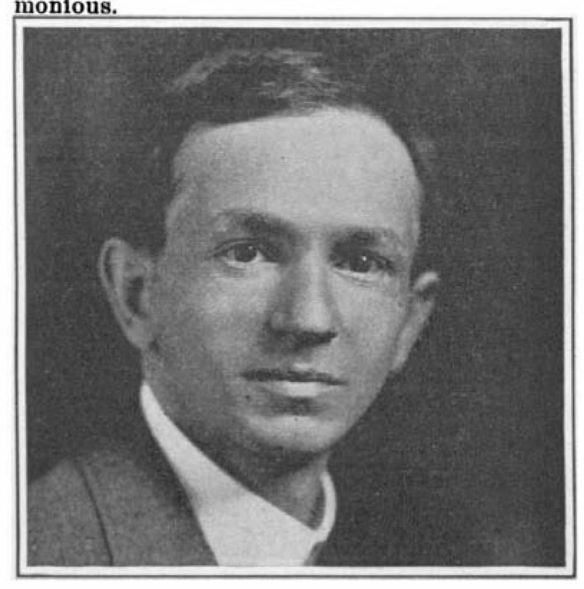

Pbuto. by Pirle nacidonalic

14-A good example of the triangular mental type. Very sensitive. Imaginative. Deportion.

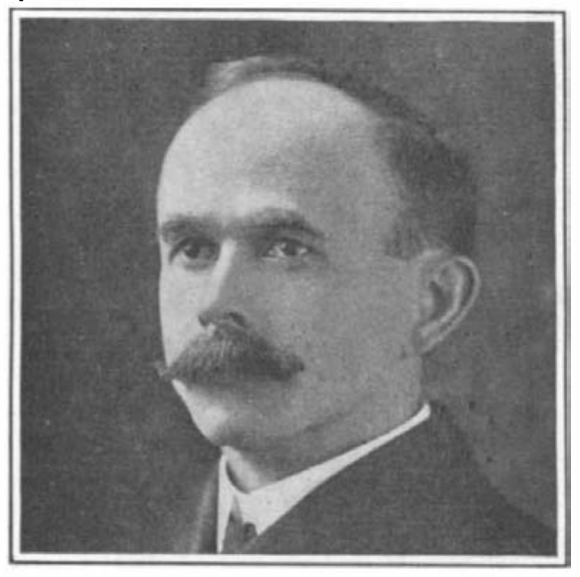

Copsrizht by Harria and Ewing.
15-A good example of fine texture. Ideal15-A good example of the texture. Humanitarian. A natural educator. Fine example of mental type. (Note triangular features.)

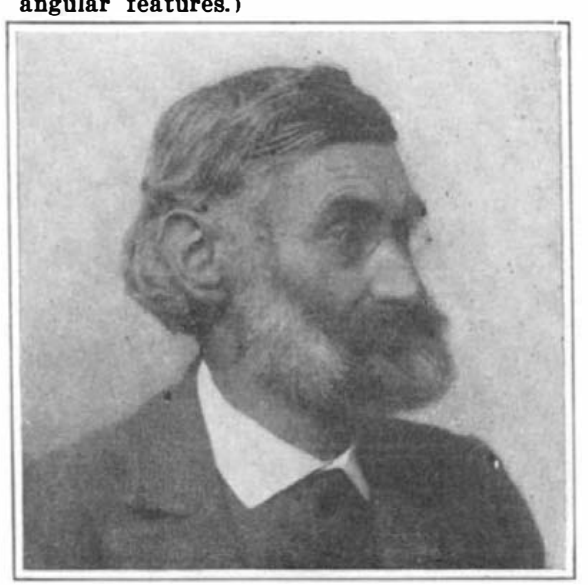

16-Concave, idealistic type. A man whose ocial ideals were so high that he converted is entire fortune into a trust fund for the

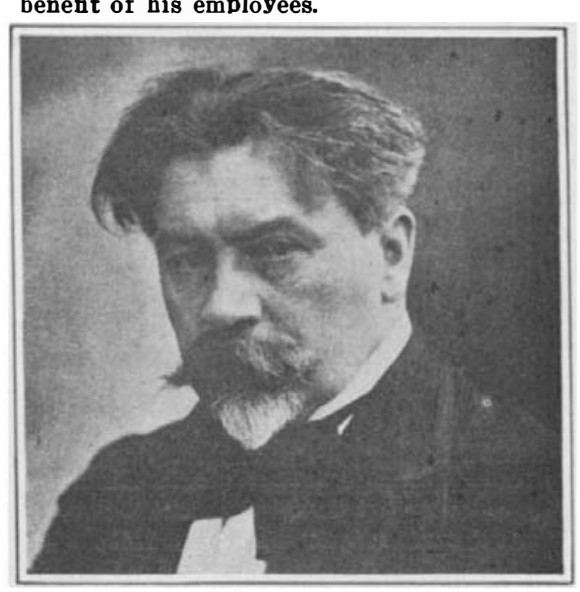

17-Convex, motive, brunette type. A dar-
ing pioneer. Original, shrewd, and penetrating pioneer. Original, shrewd, and penetrat-
ing. Keenly interested in facts, inclined to
skepticisu, hut open to conviction. Lover of gently devised methods will not be efficient unless there are men fitted by nature and training for their tasks, in the right places at the right time, and with the right training, guidance, direction, and supervision." How different is this point of view from that usually entertained! The manufacturer is prone to place his labor supply in the same category as his supply of raw material, and to think no more about it than to be sure that there are men enough to run his machines and to do his work. To the consideration of the relative cost and efficiency of two machines he will give hours; to the choice of men to run the machines he will devote scarcely ten minutes.

It is obviously unscientific to place men and women in an organization with out reference to their fitness. It is also deplorably wasteful of time and money of the employer and of time, energy and psychical inspiration of the employee. Mr. Harrington Emerson has estimated that "the yearly money lost in direct cost on the average machinist of only 30 per cent efficiency (not by any means an unusual standing) is nearly $\$ 5,000$; not counting the loss of profit on output. This loss in efficiency increases as the position becomes one of greater importance." It is but one step in advance to use the cut and try or "hire and fire" method of selection by requiring actual demonstration of fitness on the part of the employee.

Dr. Blackford has for thirteen years carefully studied men and women at their work, in their amusements, in their mental and physical ailments and abnormalities, in their religion, in their social and commercial relationships and in their crimes. She has studied them in all vocations, in all parts of the United States and Canada, and, during a tour of the world, in eighteen foreign countries. In her files she has details and complete records of her examinations of 15,000 persons, and summarized and classified records of her observations of upward of 50,000 more.

As the result of her studies she has devised a scientific method of judging character, a method which yields accurate, clear, and easily applicable information as to the requirements-in human aptitudes, training and experience-of each function in the organization; which provides for the selection of human material by methods for determining its inherent and acquired qualities; which can be taught to intelligent examiners and used in analysis rapidly, unobtrusively, and without requiring more than passive co-operation on the part of the applicant; and lastly which provides the management of any organization accurate information as a basis for associating workers and executives in such a way as to realize the greatest possible efficiency from each.

The system which she has devised deals entirely with externals. In an intuitive way we all recognize the value of external characteristics in judging human capabilities. Even our language indicates it. The "roving blue eve" is not an empty phrase. The words "thick skinned" and "thin skinned" connote both physical and psychical degrees of sensitivity. The sensitive, delicate minded man usually has a fine textured skin; the coarse-minded man a coarse textured skin. It is an embryological fact that the skin was and is the original seat of all sensations, and that spinal cords and nerves are but modified and specialized inturned skin. Of necessity a man's skin indicates the texture of his brain. Dr. Blackford holds: "It is a law of human nature having universal application that the size, color, proportion, form, texture, consistency and structure of an object indicate its function and use."

As the result of all her investigations and studies she has determined upon nine fundamental physical properties, variations and combinations of which indicate the characteristics not only of human beings, but of all other material objects, whether animate or inanimate. These nine fundamental properties are texture, size, color, form, structure; consistency, proportiom, expression and experience or use.

Each of these nine properties has a distinct manifestation in every person. For example, texture may be fine, medium or coarse. Size may be large or small and all degrees between. Form may be extremely convex in general tendency or extremely concave, with all extremes of convexity and concavity, and with all combinations of convex and concave features of face and body.

Structure may be slight and delicate, square, bony, and muscular, round and corpulent, or any degree and combination of these. Consistency may be very hard, very soft, elastic or varying gradation of these. In proportion we find almost every possible combination of proportions of different parts of the body, head, and face to one another. Expression has almost as many variations as head, and face to one another. Expression

Dr. Blackford's investigations indicate that each of the nine elements she enumerates is indicative of certain inborn or acquired characteristics of the individual.

For example, she points out, texture is a great classifier of humanity. The individual of fine hair, fine textured skin, delicately chiseled features, slender, graceful body and limbs, as a general rule, is refined, loves beauty and grace, and likes work either purely mental in.its nature, or offering an opportunity to handle fine, delicate materials and tools. On the other hand, the man with coarse hair, coarse textured skin, and large, strongly formed features inclines as a general rule to occupations in which strength, vigor, virility, and ability to live and work in the midst of harsh, rough, and unbeautiful conditions are prime requirements.

Mark well in this statement, however, the qualifying phrase, "as a general rule." Other elements besides texture may modify the final result. Also note well that these are merely suggestive examples of all of the many things that texture may indicate in the individual.

Some similarly suggestive indications of the other propertles may also be given. In size, men of small stature and light weight are obviously adapted to ligh work, and work requiring quickness and agility, while men of large stature and heavy weight are adapted to lifting and moving about large and heavy masses of material when engaged in physical work.

It is no secret to observaut employers of labor that blondes, as a general rule, are changeable, variety loving, optimistic, and speculative, while brunettes are consistent, steady, dependable, serious, and conservative.

Form is evidenced in the shape of the features, and of the entire body. It requires no scientist to observe that the greyhound is quicker, more responsive, and less enduring than the buillog. And it turns out, as one might naturally expect, that the man who resembles the greyhound in form is quicker, keener more responsive, and less enduring than the man who resembles the bulldog in form.

A most cursory examination of the portraits of poets, educators, and essayists will show a marked general tendency in them to resemble the triangle in structure of head and body - both head and body wide above and narrower in the lower (Continued on Fage 75 .)

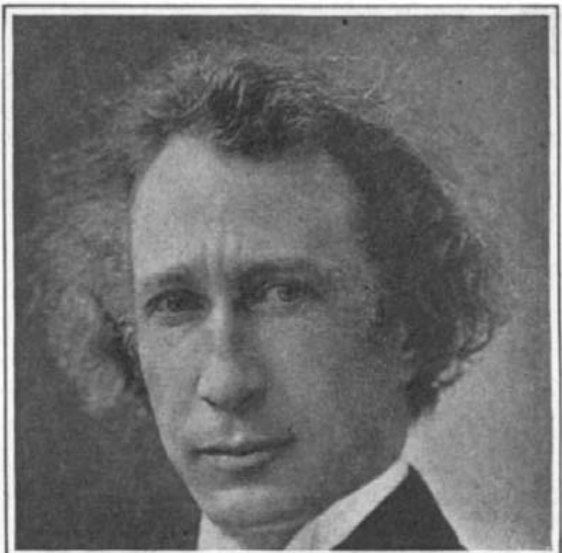

18-The fine textured sensitive artist type. Quick, kind, and responsive.

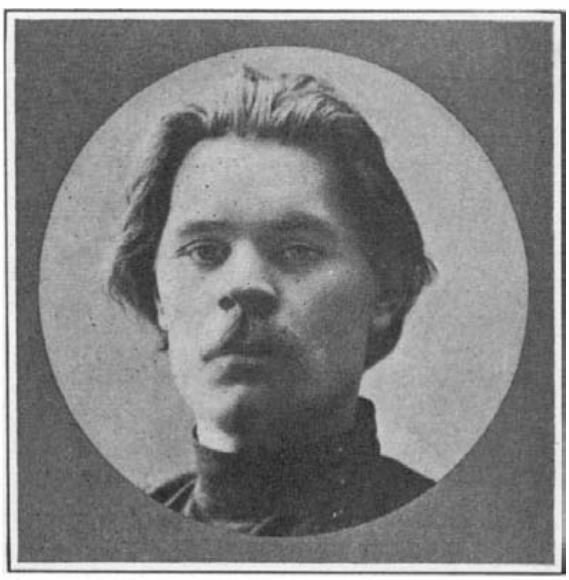

19-Russian motive type, of coarse texture forceful, vigorous, and unrefined.

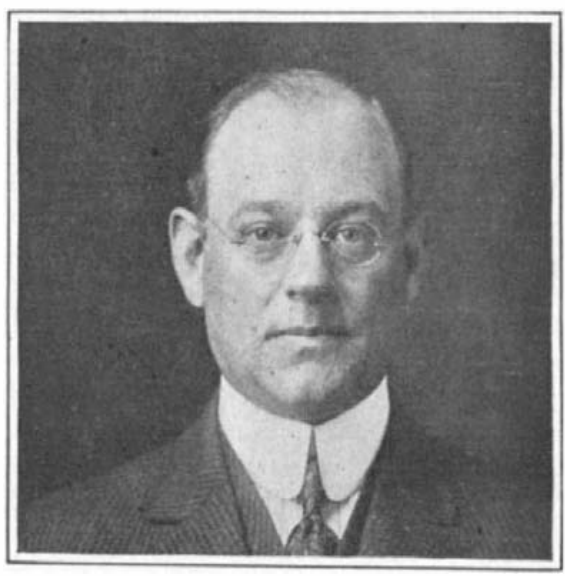

20-An executive of fine texture who wins and holds the loyalty of all grades of workingmen.

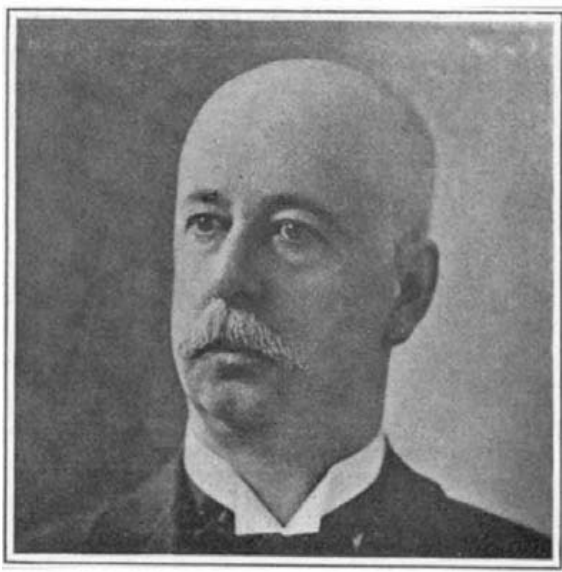

21-A good example of the promoter typeconstructive and imaginative.

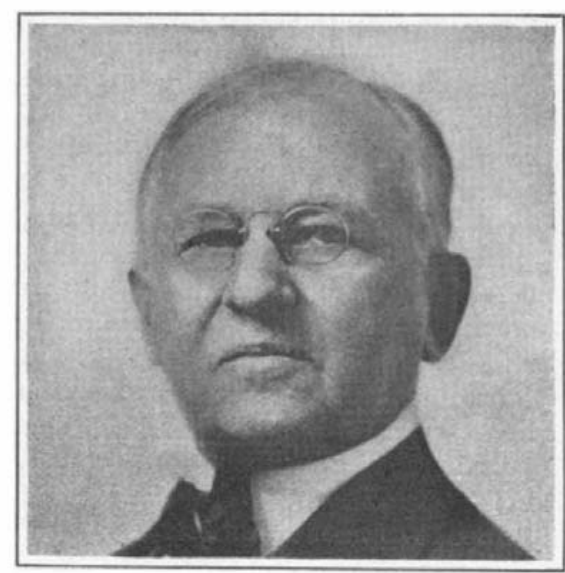

22-The commercial type-slitrewdness. fa 


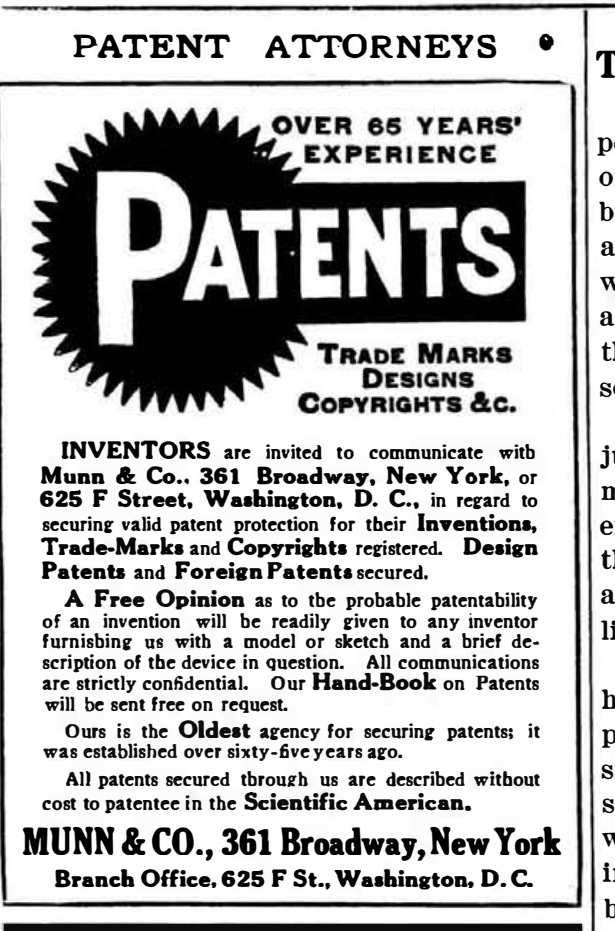

Classified Advertisements

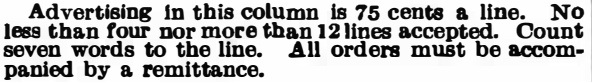

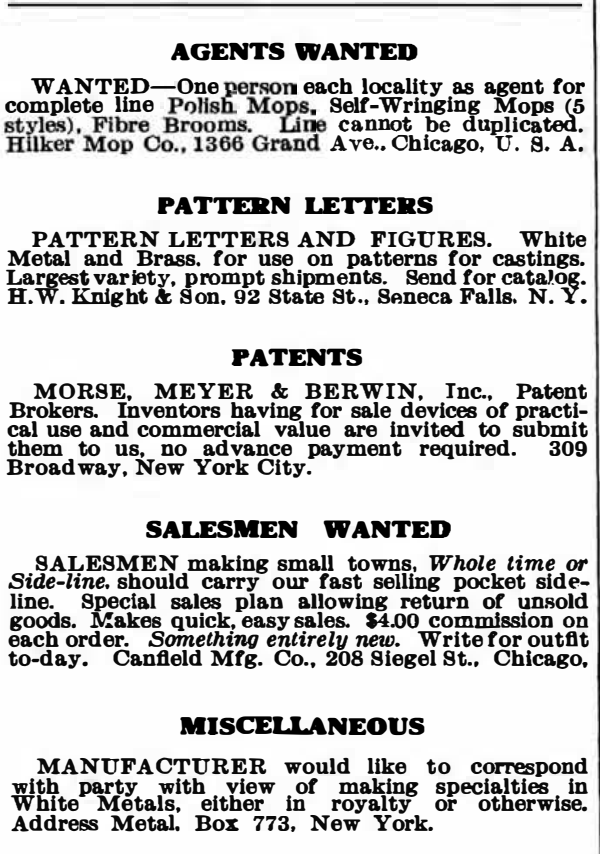

INQUIRY COLUMN

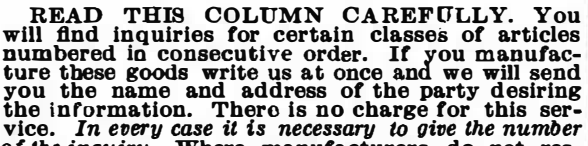
of the inquiry. Where manufacturers do not res-
pond promptly the inquiry may be repeated.
MUN \& Co.. INc.

Inquiry No. 9302. Wanted the address of the
manufacturer of the manufacturer of the Grenfeld flexible armored con-
ductors or cables. This is a double galvanized, spiral
conductor or cable. Inquiry No.9303. Wanted the name of manuifac-
turer who could make newly patented articles made
rom 13 to 22 gage sheet aluminum Inquiry No. 9304. Wanted the names and ad cleaning machine on the order of a carpet cleaning Inquiry No.9305. Wanted the name and addrese
of concerns making paper letters and figures. Inquiry No.9306. Wanted small hard ware and
other specialties to be sold in notion and grocery
stores, Wanted to buy wholesale Inquiry No. 9307. Wanted to buy a machine for
honlng and stroping safety razor blades on $\alpha$ comInquiry No. 9308. Wanted woven glass fabric for
manufacturing purposes in large quantities. The Inquiry No. 9309. Wanted to buy small woven
tubing of small diameter for use over the temple of spectacles where they go around the ears.
Inquiry No. 9310 . Waited addresses of manu-
facturers of good seling articles for mail order business caterine to the trade or agents.
Inquiry No. . 311. Wanted names and addresses
of manulacturers of hatpin heads made of colored glass; also medals of all shapes.
Inquiry No. 9312. Wanted to buy a machin Inquiry No. 9312. Wanted to buy a machin
which will pick up a weight the size of a lima bean
by vacuum process. by vacuum process. Must be able to pick up and be
gravel, etc. Must be operated by electricity and bortable. Inquiry No. 9313. Wanted to buy Leather Held
Horse Shoes uard temporarily when shoe cannot be
nailed on. In uther words a Leather Boot with iron shoe at bottom-strapped over horse's foot.
Inquiry No. 9314. This enquirer is in the market and manufacture with an investment of from 85,000
to s10,000. The name of the party will be supplied
to any of our readers on application Inquiry No. 9315. Wanted the name and addrese
of a concern manufacturing novelty ink wells. Inquiry No. 9316. Wanted the names of manu-
facturers and manufact urers' agents who make patanted articles and other usetulu devices which appeal
to the public and which can be used in a mall order
business and by canvass ers. Inquiry No. 9s17. Wanted the names and ad
dresses of manufacturers of good selling articles that certain territories can be ablic where exclusive sale
to the trade and through subth to sel house canvas. applianses such of coir dust, with special reference fo
The Scientific Employment of Men (Continued from page 69.)

portions. An examination of the portraits of a hundred great generals, pioneers, builders, engineers, explorers, athletes, automobile racers, aeronauts, and others who lead a life of great activity will show a general tendency toward structure on the lines of the square-square face, square body, square hands.

Reference to the portraits of great judges, financiers, organizers, and com mercial kings will show a general tendency toward structure upon the lines of the circle-round face, rounded body, and a tendency to roundness in hands and limbs.

Anything which is hard in consistency has comparatively great resistance and persistence. That which is elastic in consistency is adaptable and seems to have spring, life, and energy within it. That which is soft in consistency is pliable and impressionable. These principles have een found to apply to human beings. Relative development or proportion of the different parts of the head, face, and organs of the body to one another is, in the eye of a physician, the anatomist, and the expert analyst of human character, an indication as to the relative degrees of the three qualities of energy, vitality, and endurance-and of many other charactertistics.

Men's emotions, thoughts, and tend encies show themselves in the expression of the face, quality of voice, gestures, walk, clothing, etc. Since the human body is plastic, any emotion, thought, or tendency which has become habitual leaves its permanent mark in all the forms of expression.

"Normally" says Mantegazza, "every thought and emotion takes form in action A transitory emotion has a fugitive expression which leaves no trace, but when it is repeated several times it leaves on the face and other parts of the body an expression which may reveal to us a page of the man's history."

In a similar way, a man's experiences eave their marks upon him.

The foregoing is a summary, greatly bridged, of the indications of each of the nine elements upon which Dr. Blackford and those using her plan base their judgment of qualities and characteristics. Far more important however, than any De of the nine elements is their combinaion in the individual. Every individual has his equipment of all nine, and his personality cannot be understood if the significance of even one of the nine is erlooked.

The importance of this consideration ay be made clear by chemical analogy. student of chemistry may learn all the haracteristics of oxygen, carbon, and hydrogen, but he may know nothing of the attributes of their many compounds until he has learned the significance of heir combination in different proportions. Just as all human beings are combinations of the nine elements mentioned, so all carbohydrates are combinations of oxygen, hydrogen, and carbon.

Just as carbon, oxygen, and hydrogen in one compound give us fiery, caustic, and poisonous carbolic acid, and, in different proportions, sweet, healing honey, so the ine elements, combined in certain proportons, may make of one man a degenerate thief and murderer, and of another man a patriotic and philanthropic citizen.

The analogy may be carried even further. Oxygen is a gas lighter than air, colorless, slightly acid in odor and taste. Hydrogen is also a gas very much lighter than air, colorless, odorless, and asteless. Carbon is a solid, and usually hard, dense, and black.

None of the characteristics of any of these three elements are to be found in butter, molasses, phenacetin, or peppermint. Yet these three, and these three only, are in the substances named. In a imilar way, combinations of the nine elements of human character in different proportions yield characteristics not indicated by any one of the nine. For ex ample, a man's honesty, his disposition (Continued on page 77.)

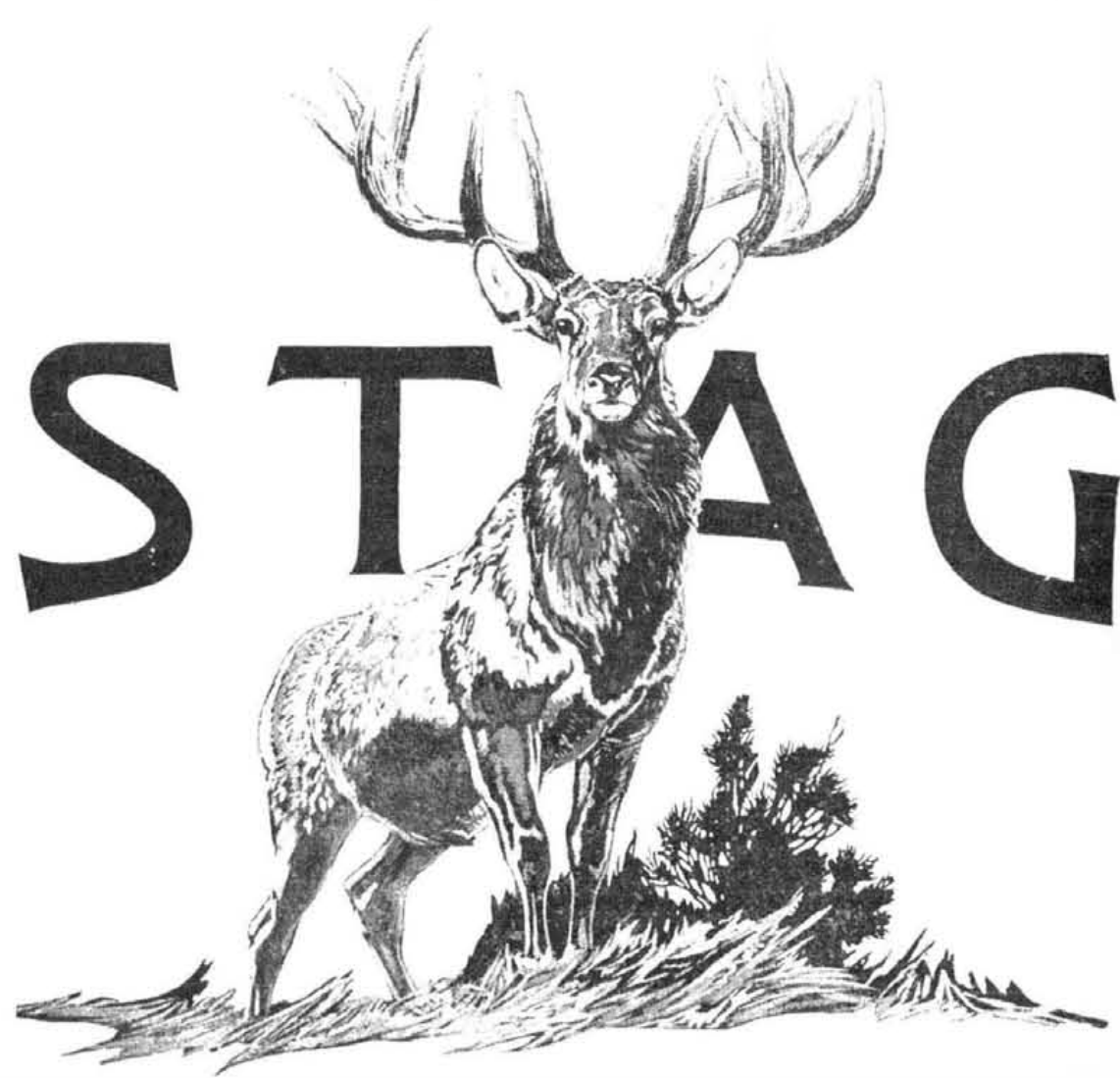

THE highest
grade smok-

ing tobacco made-80 cents a pound.

But packed in a handy 5 Cent tin just HALF the ordinary size.

Exactly enough to keep FRESH and PERFECT until you have smoked it ALL.

The most delightful FRAGRANCE, the

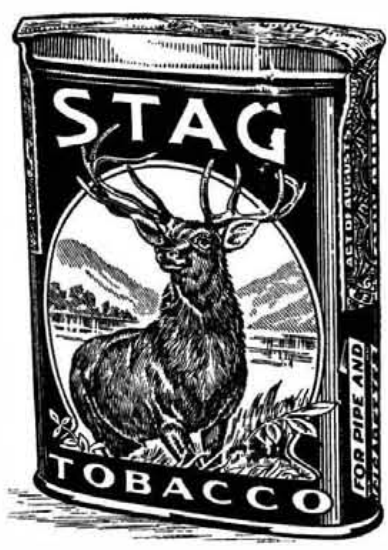
FINEST SMOKE, the HANDIEST TIN in the whole history of tobacco.

Sold only in Handy 5 cent tins and 90 cent pound glass humidor jars

“EVER-LASTING-LY GOOD”

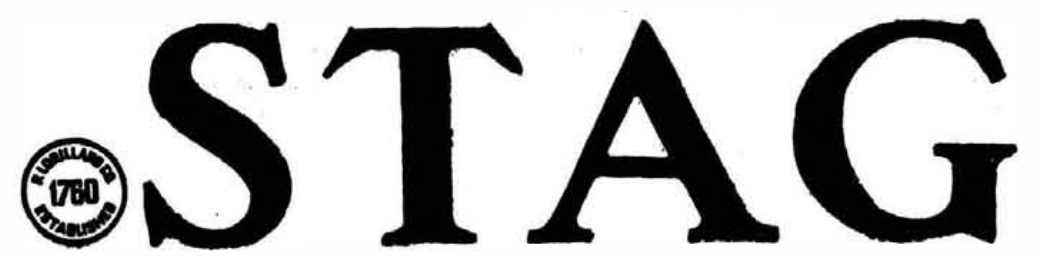




\section{Valuable Books}

The Modern Gasoline Automobile

ITS CONSTRUCTION OPERATION, MAINTEN-

By VICTOR W. PAGE. Octavo. 693 pages, over 400
illustrations and folding plates. Price, 22.50 .

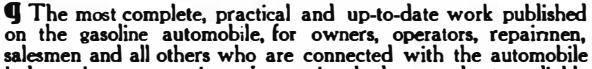

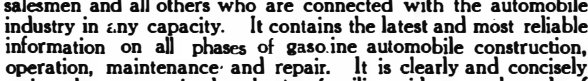

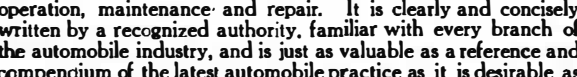

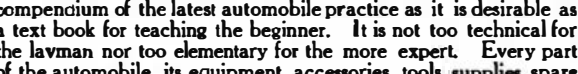

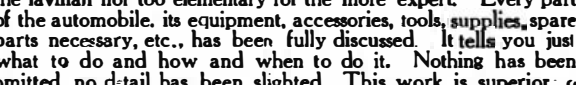

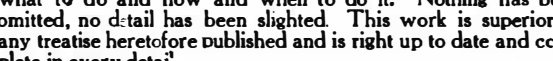

Scientific American Reference Book

\section{EDITION OF 1913.}

Compiled and Edited by ALBERT A. HOPKINS and
A. RUSSELL BOND, 12 mo., 597 pages, 1000 illustra-

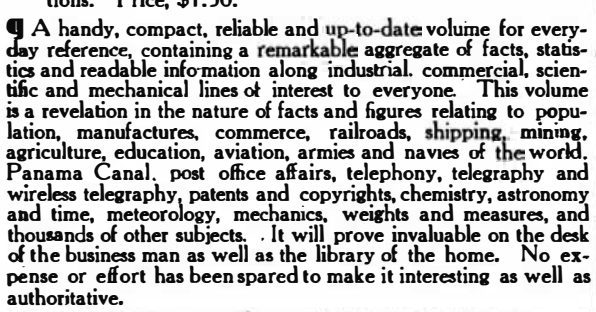

Wireless Telegraphy and Telephony Simply Explained

\author{
BYALFRED P.MORGA
}

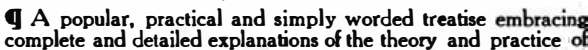

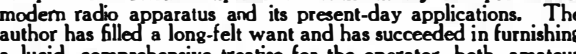

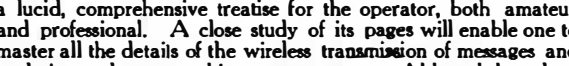
sciesign and construct his own apparatus. Although based on
scienticc principles, no attempt has been made to give mathemati-
cal explanations. It is written so that it can readily be undercal explanations, It is written so that it can readily be und
thood m men who are not technical and at the same time
sufficiently comprehensive and practical to be studied advant

The Scientific American Handbook of Travel

With Hints for the Ocean Voyage, for European Toun
and a Practical Guide to London and Paris. Compiled and Edited by ALBERT A. HOPKINS. 12
mo. 503 agage, 500 Hillustrations. Price, Hexible cloth,
$\$ 2.00$; full flexible leather, $\$ 2.50$.

- This is an indispensable companion fint the European tourist and contains more miscellaneous information on travel and sub-
jects of interest to travelers than can easily be lound in any other
form. It is unlike any other guide that has been published and orm. It is unlike any other guide that has been published and
is not intended to take the place of descripive guides, but as
complement to all of them. It also forms an excellest referen volume for all in any way interested in the ocean and its nave
zation, as it contains many facts presented in an interesting and
readale form and tells you exactly what you have wanted eadable form, and tells you exactly what you have wanted to maps of Paris and London. a completeantomobile roadmap
Europe, and several other mass are included in a pocket at the

The Scientific American

Cyclopedia of Formulas

Edited by ALBERT A. HOPKINS. Octavo, 1077
pages. 15,000 Receipts. Cloth, $\$ 5.00$; half morocco,

g. This valuable work is a careful compilation of about 15.000
selected formulas, covering nearly every branch of the usefu

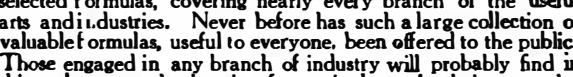
Those engaged in any branch of industry will probably find
this volume much that is of practical use in their respective

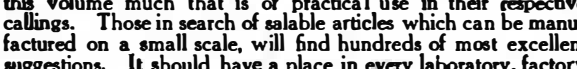
and home

\section{Concrete Pottery and} Garden Furniture

By RALPH C. DAVISON. 16mo., 196 pages. 140 This book describes in detail in a most practical manner the various methods of casting concrete for ormamental and usefu
puposes. It tells how to make all kinds of concrete vases
ornamental flower pots, concrete pedestals, concrete benches ormamental flower pots, concrete pedestals, concrete benches
concrete fences, etc 5 .t.ll practical instructions are given for
constructing and finishing the different binds of molds, making the wire forms or frames, selecting and mixing the ingredients, cover
ing the wire frames, modeling the cement mortar irito form
and casting and finishing the various.objects. With the informa and casting and finishing the variausobjects. With the inform
tion given in this book, any handy man or novice can male
many useful and ornamental objects in cement for the adorn many useful and ornamental objects in cement or the adorm
ment of the home or garden. The information on color work
alone is worth many times the cost of the book.

Any of these books will be sent post

paid on receipt of advertised price.

MUNN\& CO., Inc., Publishers 361 Broadway,
(Continued from page 75.$)$

loyalty, his industry, his carefulmany other such qualities cannot be determined by an observation of any one of these nine elements alone, but can be unerringly appraised by careful observation and analysis of the proportion in which the nine elements are combined. It is abundantly clear, from the foregoing, that the character analyst who attempted to judge of the qualifications of applicant for a position merely because exion, would go as far wrong as a chem who analyzed a carbohydrate quantatively for carbon and hydrogen, but neglected to do more than determine the presence of oxygen.

Camphor and olive oil have approximately the same proportion each of carbon and hydrogen, but because of a ver and one is aromatic, strong to the taste, and one is aromatic, strong to the taste, and poisonous; the other is mild, soothing, and
so two men may be almost exact counter-parts of each other in texture, size, form, color and consistency, but account of a difference in proportion, pressions, and experience, one will be a zy, shiftless, careless, irresponsible buren upon society, and the other a succes ul financier.

It is well known that certain chemicals unite to form useful substances, and that others unite to form either useless or actually explosive and destructive substances. It is also well known that certain men seem to co-operate and harmonize with one another most efficiently, and that certain other men cannot be associated together without inharmony more or ss violent.

Just as chemical analysis enables the experienced chemist to determine which hemicals he desires to mingle in order to obtain desired results, so the experienced analyst of human character has learned how to associate different types of executives and employees to secure the rea test efficiency.

It is evident that a man or woman without unusual gifts can study signs based upon the foregoing nine principles, learn the meaning of their compounds, and become skilled in the selection of men and women for their fitness for functions in which have been carefully pre-determined. That this can be done is demonstrated y the success of employment departments nstalled by Dr. Blackford, and conducted y those whom she has trained.

The conclusions reached by Dr. Blackord and her assistants are sometimes peedily and strikingly verified.

employment plan was first installed in a certain factory where many electric cranes were in use, and before there had been time to analyze fully the requirements of all the different classes of work, a requisition was received by the employment department for ten crane operators and twelve crane hookers. The who received the telephioned the superintendent to inquire something about the work to be done, and the qualifications necessary for its efficient performance.

Among other things, the superintendent said: "This work is rather dangerous, and a careless man might get himself and his fellow workmen seriously injured or killed, so send me men who are ver careful."

With this instruction in mind the assistant analyzed a number of applicants, and from them selected fifteen-the fifteen who, with other requirements, were nat urally the most cautious and careful. Not one of the fifteen, when his prospective duties were explained to him by the superintendent, would take the posithat offered. They were all so cautious gerous work !

A Safety Device for Moving-picture Apparatus.-Charles H. Converse and William H. C. Rider, of Chicago, have secured patent No. 1,062,081, for a picture-pro-
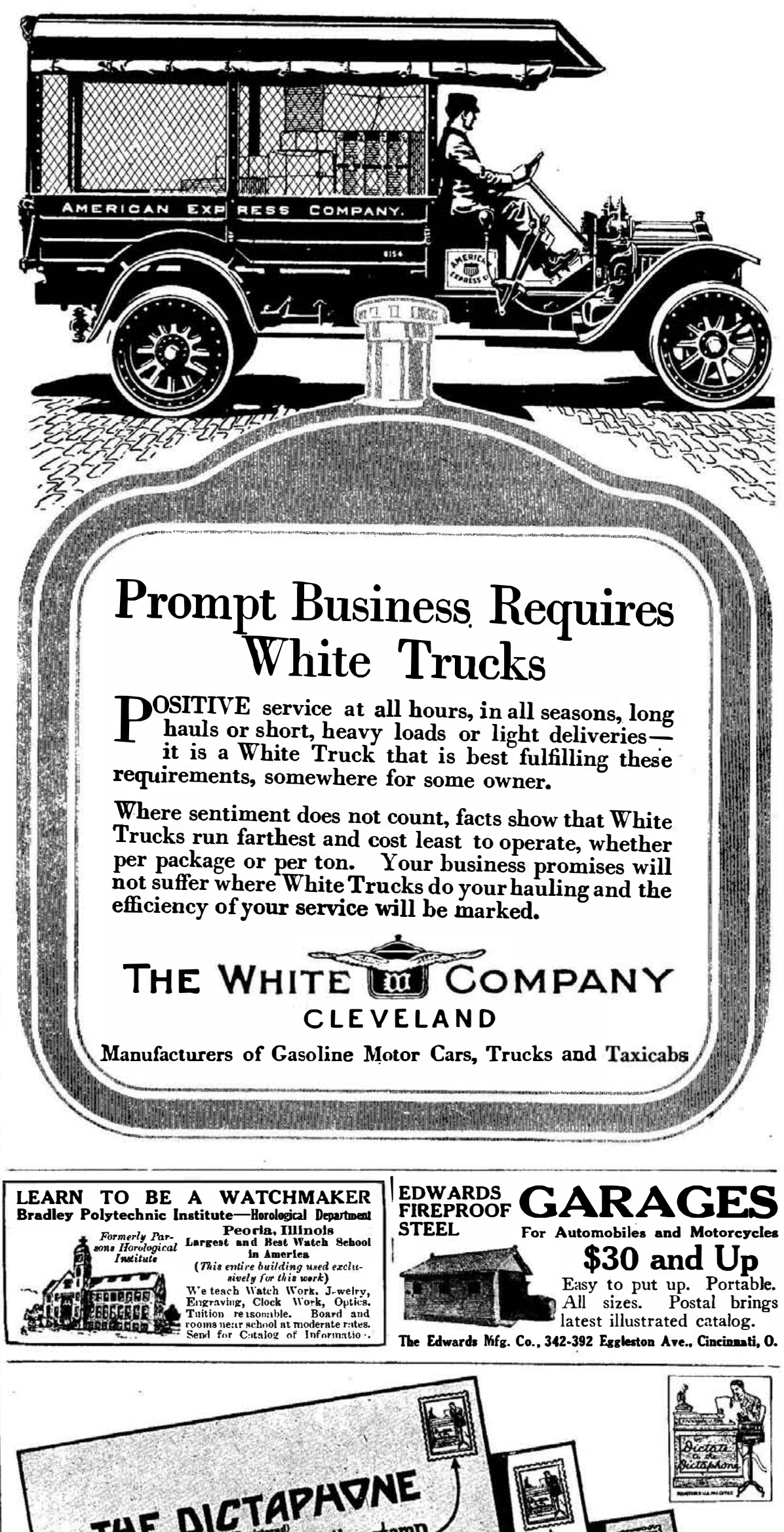

TAE DICTAPHONE

Saves you the cost of the mail.

on every letter you mall

on every letter you mail.

on every letter you mail.

ND that's the smallest part of the effi-

A ciency-value of the Dictaphone to you. It does enable your typist to turn out twice as much work, but it also enables you to dictate better letters, and do it as fast as you like, and whenever you please-just as you would talk to your telephone.

Demonstration by appointment in your own office on your own work. Reach for your telephone and call up "The Dictaphone." If you don't find that address in your telephone directory,

DICTAPADNE

148 Graphophone Company, Sole Distributora)

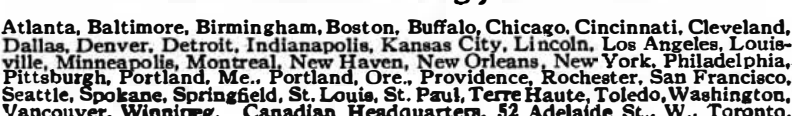

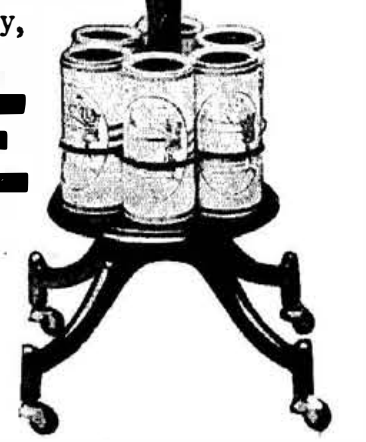



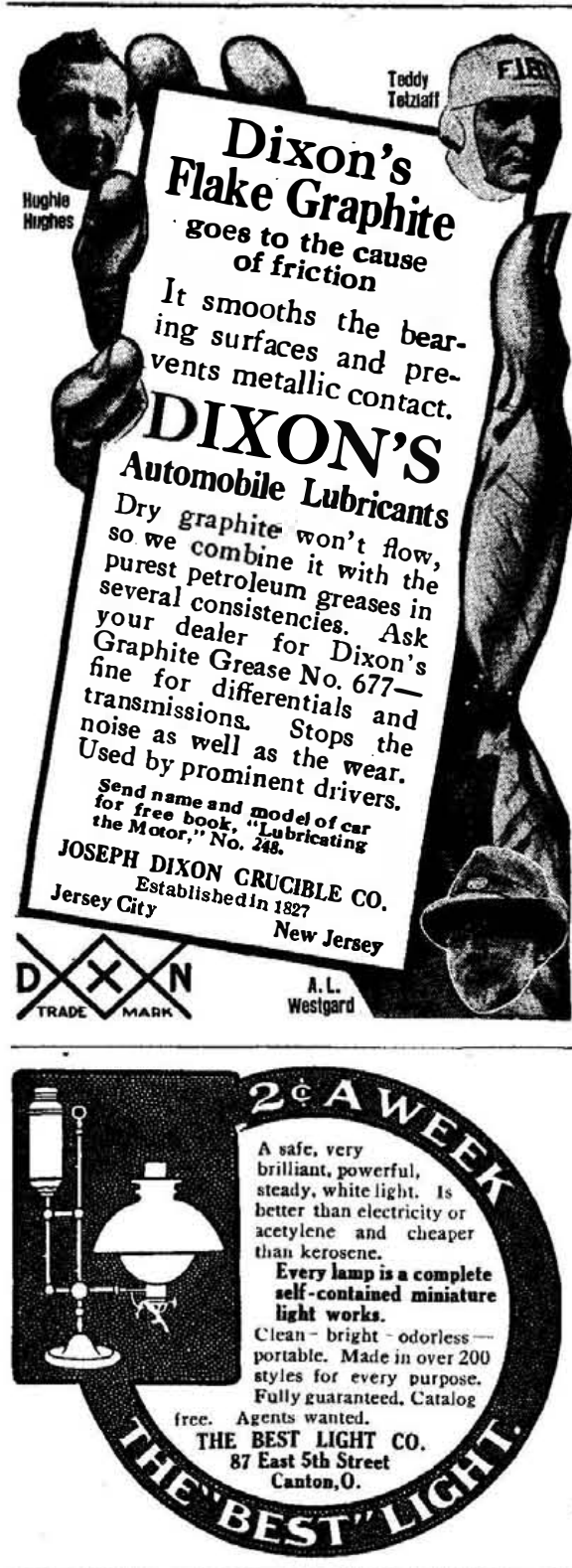

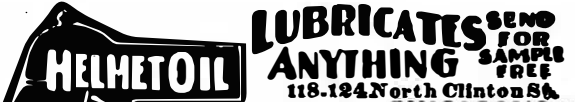 Cribes ivaca fintifofousA}
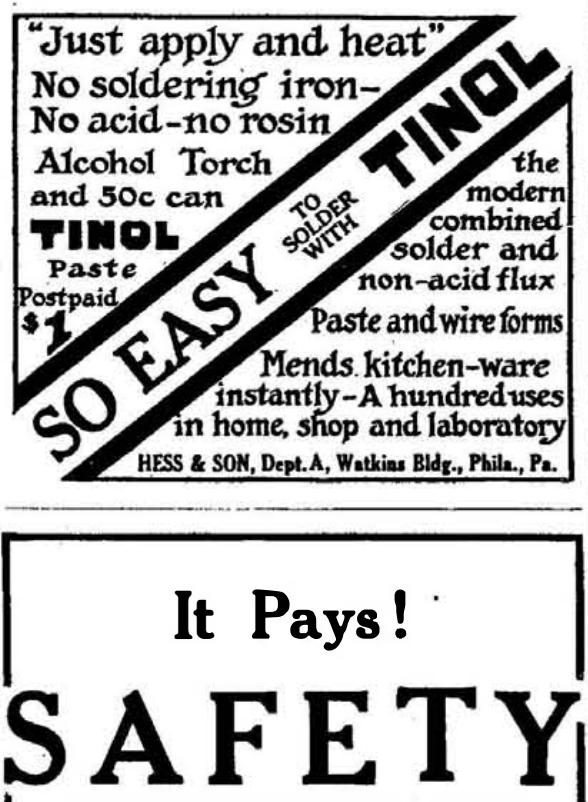

Methods for Preventing Occupational and Other Accidents and Disease

\section{WILLIAM TOLMAN}

\section{LEONARD B. KENDALL}

Safety pays - that is the message this book brings to business. It is the result of years of study of the new industrialism from the point of view of safeguarding the human factors. After reading these pages the factory owner, superintendent or shopkeeper will be convinced that money willingly spent in prevention is better than that extorted for compensation. from the lamp are absorbed by interposing life-boat track which extends from the deck a protecting screen between the light and down alongside the vessel to the water line the film. The protecting screen is described and is so supported that it may be swung as a celluloid sheet coated with a gelatinous from a position extending transversely out solution.

\section{The Wire Industry}

TATISTICS for the wire industry in
the United States for 1909 are pre sented in detail in a bulletin soon to be
issued by Director Harris of the Bureau issued by Director Harris of the Bureau
of the Census, Department of Commerce. of the Census, Department of Commerce.
It was prepared under the supervision of William M. Steuart, chief statistician for manufactures.

The manufacture of wire in the United States is carried on by three classes of establishments: (1) Establishments whose
principal business is the drawing of wire principal business is the drawing of wire
from rods which are either purchased or transferred from independently operated rolling mills of the company, thus including the detached and independently ope wire rods; (2) establishments that roll iron and steel, copper or other metals or alloys, and maintain wire-drawing departments supplied with rods from the co-operating rolling mills; and (3) establishments whose principal business is the manufacture of some quite different product, but which incidentally draw some wire,
usually as material for their own conusually
sumption.

sumption.
There are many establishments which draw no wire, but which manufacture wire goods (fencing, wire cloth, springs, lishments are not covered by the ensstatistics for the wire industry.

The total number of establishments in the United States in the wire industry as a whole in 1909 was 93 , of which 56 were wire-drawing mills proper which purchased the wire rods used, 31 were wire wire departments of other concerns.

The total value of the products of these 93 mills or wire departments was $\$ 180$,-
083,522 , of which $\$ 173,349,614$ consisted 083,522 , of which $\$ 173,349,614$ consisted
of wire and products derived therefrom. Of this latter amount, 45.7 per cent represented the value of products of the wire mills and 50.8 per cent that of the wire departments of rolling mills.

Data regarding the wire industry as an entirety are not available for 1904 an 1899 , but an approximate idea of its growth may be gained from the statistics of the production of wire rods of iron and steel. The output of such wire rods in 1899 was 916,587 long tons; in 1904, 1,792,704 long tons, and in 1909, 2,295,279 long tons, the increase for the decade being 50.4 per cent.

The large plants predominate, especially among the wire departments of rolling mills. The 24 wire departments of rolling mills whose product exceeded $\$ 1,000$,407,015 , or almost one half of the total
and of products of the industry.

Of the 93 establishments in the industry in 1909, 59 drew iron and steel wire exclusively, 7 drew copper wire exclusively, 6 drew wire from materials (chiefly brass) other than iron and steel
or copper, while 21 drew wire from two or more of the metals. A large proportion of the establishments manufactured wire nails, barbed wire, woven wire, and other
products for which plain wire is the principal material.

Of the total expenses reported by wire mills in 1909, salaries represented 2.8 per cent; wages, 13.3 per cent; cost of mate-
rials, 78.2 per cent; and miscellaneous exrials, 78.2 per cent;
penses, 5.7 per cent.

penses, 5.7 per cent.
The cost of materials in 1909 represented 71.7 per cent of the total value of products, and the value added by manufacture, 28.3 per cent.

The total number of persons engaged in wire mills in 1909 (not including the wire departments of rolling mills) was 19,945 , of whom 18,084 , or 90.7 per cent, we wage earners.

A Rapid Service Life.boat System.-In patent, No. 1,062,637; Melvin D. Conk lin, of New York city, provides for the rom the vessel to one lying against the side of the vessel.

French Fisheries on the Newfoundland Banks

Two recent consular reports from St Pierre call attention to the many in Banks. This industry is more than 400 years old, and has changed but little with the progress of the centuries. The only portant innovation was the substitutio light dories for the clumsy "chaloupes" n use prior to 1865 . It is true that withhas appeared as a rival, but not yet a ngerous rival, of the brig and schooner n 1912, 240 vessels and 6,838 men enat is known as the "metropolitan" et, i. e., vessels fitted out in Normand nd Brittany. These vessels leave France cording to wind and weather. The voyge is perilous, for the craft are ver methods of navigation are the simplest. The masters of these mine their longitude with any accuracy oughly from soundings when they have
arrived at the Banks; returning they estimate their position when they cros the steamer lane
English Channel.

Besides the metropolitan fleet, a ce number of vessels (40 in 1912) are fitted out in the colony of St. Pierre and Mruelon and manned with Normans and Bretons who come out in the spring on steamer chartered for the purpose and Formerly these men made the journey in sailing vessels, which were often dangerously crowded. The combined fleet 1912 numbered 7,500 fishermen.

The fishermen do not work for wages, before the eave France they receive an advance paynot infrequently happens, a man's share at the end of the season is not sufficient to cover the amount advanced to him, the owner of the vessel loses the difwith empty pockets. The fisherman'
. total earnings in seven months of hard abor and exposure probably do not averlot, and all the reforms that have been effected toward improving their wages and the conditions under which they labor have been initiated by naval officers, ad owners, and persons engaged in the société des Oeuvres de Mer.

The American Mining Congress M ANUfaCtURERS of mining machinand safety appliances are to be given an the mining men of the country at a great auspices of the American Mining Congress, in Philadelphia, Pa., the week ctober 20th.

This exposition, the first of its kind in this country, will be held in conjunctio With the annual convention of the Minin pected to attract thousands of interested men. It will be entirely national in scope the metal mining interests of the West $t$ be coal mintive plan to have a gold mining camp in full operation with a mill crushing the e. Horticultural Hall, the biggest place eart of the city, bas been engaged for teresting and unique features of the
French fisheries on the Newfoundland ged in the Banks fisheries constitute rom 14 to or early April and requir have no chronometers and cannot deterOn the outward journey they can tell deducted from their future earnings. If the more than $\$ 150$. Strangely enoug opportunity to display their wares before

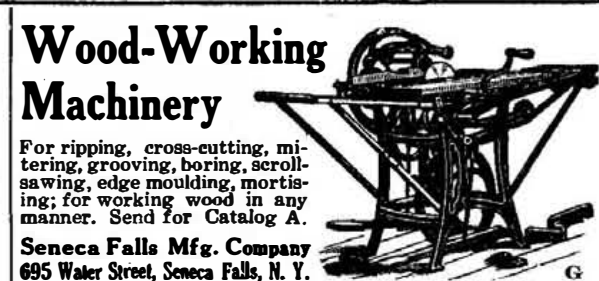

Good Lathes

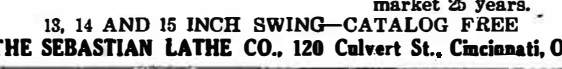
ForGunsmiths, Tool Makers, Experimental \& Repair Work, etc.
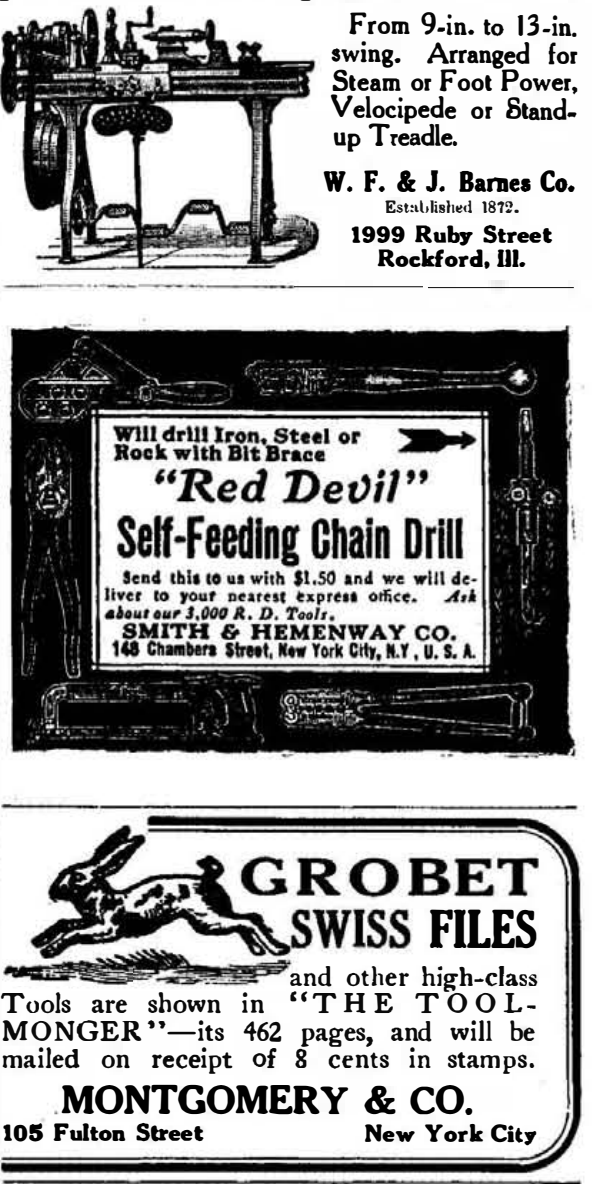

WELL MACHINGS

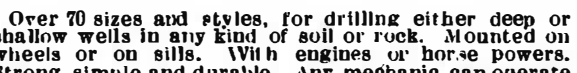
WILLAMS BROS, Ithaca. N. Y.
WIL Send focatiog.

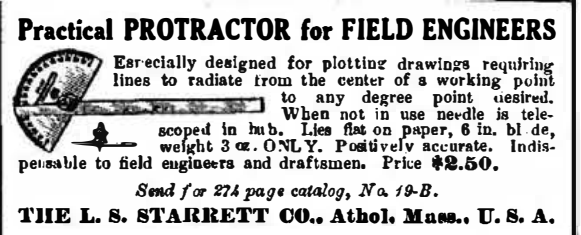

EPICYCLIC TRAINS, which play an important toothed gearing, are ably de 10 cents sale by Munn \& Co., Inc., and all newsdealers. $^{2}$

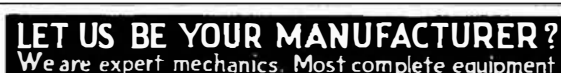
machinery. Can develop and simplify your inventions,
THE NAGEL-CHASE MFG. CO. 156 -17OE. ERIE ST.CHICAGO. ILL

Models and Experimental Work INVENTIONS DEVELOPED

E. V. BAILLARD CO., 24 Frankfort St., N. Y

NOVEL TIES \& PATENTED ARTICLES

E ROHIGSLOW STAMPING \& TOOL WORKS, CLEVELAND. 0

Patented Articles and Metal Specialties MANUFACTURED BY CONTRACT

H. CARSTENS MFG. CO., $567 \mathrm{~W}$ Wic Lake St.

LEARN WATCHMAKING

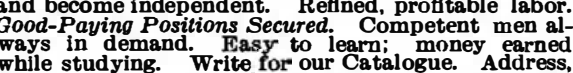
ways in demand. Fasy to learn: money earned
while studying. Write for our Catalogue. Address,
St. Loais Whatchanting School, Dep't 6. St. Louis, Mo.

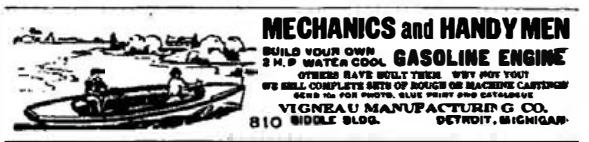

FROM NOTHING TO NINE MILLIONS

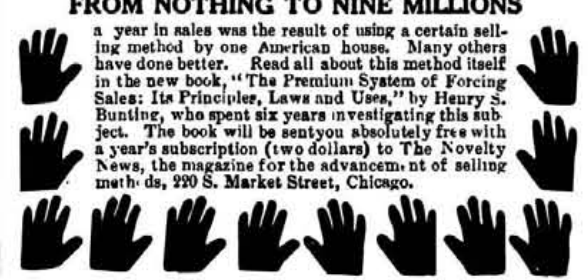




\section{Colonel Goethals' Private Car}

" "T HE YELLOW DEVIL" is the pet

Tame by which Panama Canal workers know the private motor car of Colonel Goethals. It is apparently a combination of automobile and "dinky," as it has a powerful gas engine with hood like :II automobile and a cowcatcher like a locomotive. It runs on the tracks of the Panama Railroad and will take the chief eugineer to any part of the work where the railroad tracks run. In front of the odd radiator on top of the coach may be seen a powerful searchlight, while a simiar one is mounted at the rear. This sends its rays to any point that may need special inspection during a night trip.

\section{Aerial Divers}

$T^{\text {HE highest point on the face of the }}$ T earth rises 28,002 feet above the sea. This peak of Mount Everest pokes its nose above the life-sustaining stratum of the earth's atmosphere. To reach such an elevation, it is quite as necessary to employ oxygen supplying apparatus as it is for the diver who descends into the sea. The highest point ever reached by man without the aid of special breathing appawithout the aid of special breathing appa-
ratus was 8,600 meters or about 28,200 ratus was 8,600 meters or about 28,200 feet. This was on April 18, 1878 when the balloon "Zennith" left La Vilte with three passengers aboard and came down three hours later with two or the pas sengers. MM. Sidel and Croce Spinelli, dead. That record for height has just dead. That record for height has just
been broken by a wide margin by the Jalloon "Icare," which, on May 28th of this year, left Lamotte-Breuil, rose to an altitude of over ten thousand meters, or nearly thirty-three thousand feet, coming to the ground five hours later. Two of the passengers, MM. Bienaimé and Jacques the passengers, MM. Bienaime and Jacques schneider, were photographed by the third passenger, Albert Senouque, at the 10,000
meter elevation. The photograph is re meter elevation. The photograph is re produced well bundled against the prerom and each fitted with an oxygen-breathing and each ftted with an oxygen-breathing apparatus. Each apparatus consisted of a container for 1,600 liters of compressed oxygen, a nose and mouth attachment connected to the container and a means for regulating the feed of oxygen as needed.

Railway Automobile Newspaper $D_{\text {apolis, Ninn., to Glacier National }}^{\text {URING the Glidden tour from Mine- }}$ Park, Montana, July 11th to July 19th, a daily automobile newspaper was printed on the hotel train of the Great Norther Railway, which accompanied the automobile tour to furnish eating and sleeping accommodations for the motorists. The newspaper plant was installed in a dynamo baggage car. The plant included a linotype machine, a cylinder press, and an engraving outfit. The staff photographer's daily story of the tour was tol with halftones prepared in the engraving plant - The accompanying photograp "To run the plant a four horse-power.motor was used. which obtained its power from the car dynamo.

\section{A Noise Orchestra}

IN order to add a touch of realism to $I_{\text {moving picture exhibitions, it is custom }}$ ary to punctuate the pictures with the noises one would hear if he saw the same cenes in real life. Heretofore this bas been done only occasionally and halfheartedly for the reason that many of the sounds called for were difficult to imitat without special apparatus. However, machine was demonstrated at the recent moving picture exhibition at Grand Central Palee whereby any ferent lifelike imitations can be produced ferent lifelike imitations can be produced
by merely turning the proper crank or by merely, turning the proper crank or
pressing the proper pedal. This stage pressing the proper pedal. . Cis stage noise cabinet is the invention of $\mathrm{Mr}$ Samuel Lapin. More the ous sounds can be produced. are all sorts of domestic and wild animal calls produced, but also mechanical sounds. For instance, there are fifteen

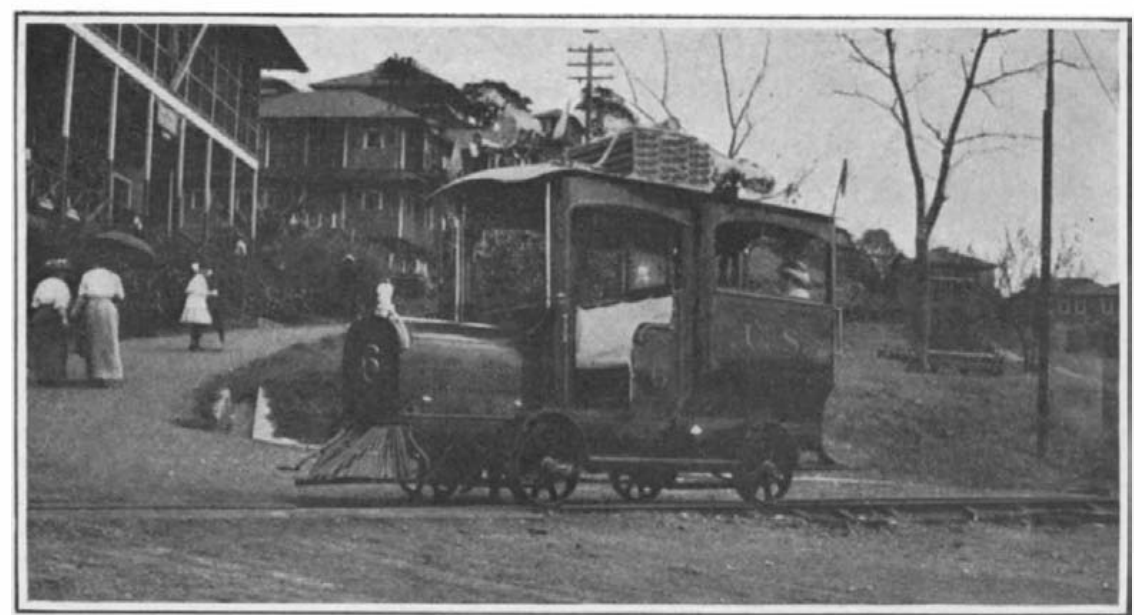

The "Yellow Devil," Colonel Goethals' private car.

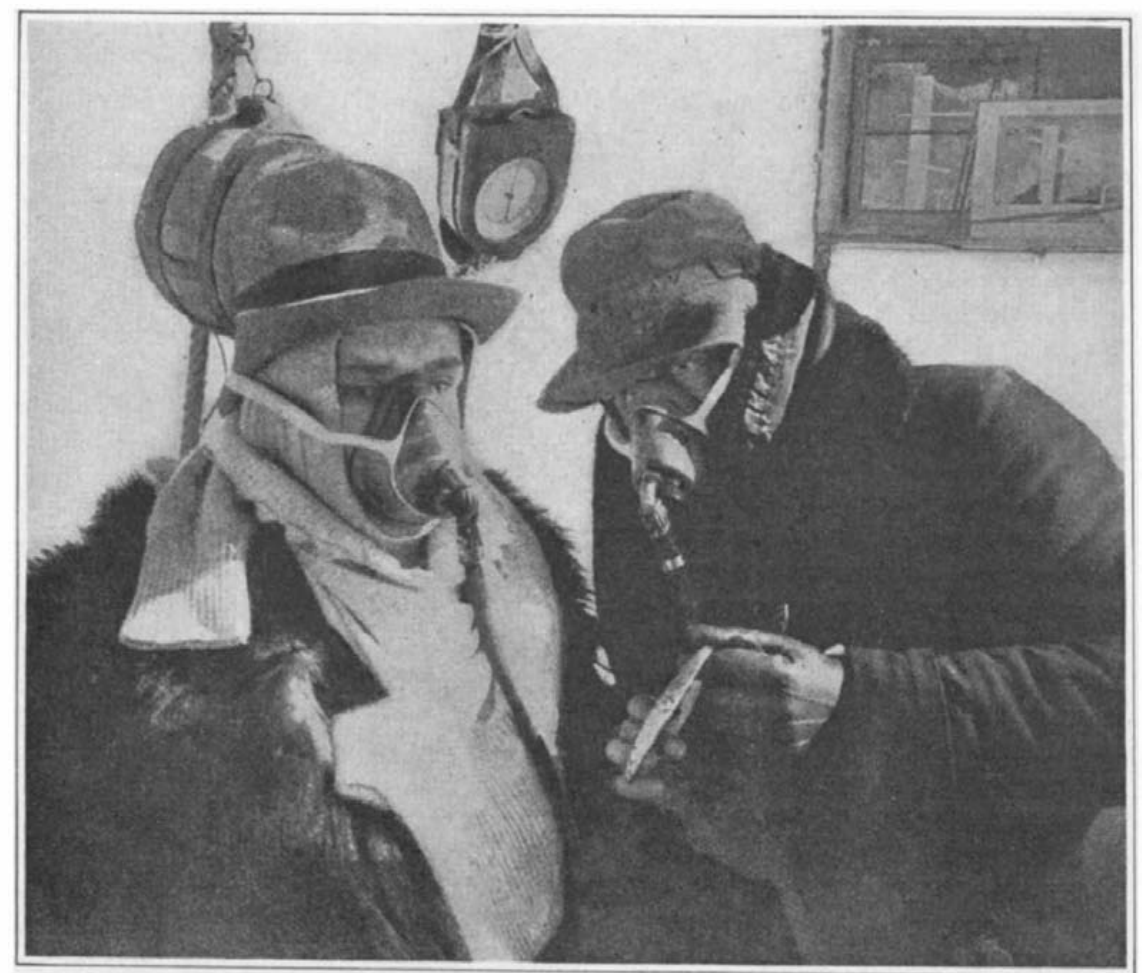

Photographed in a balloon 33,000 feet above the level of the sea.

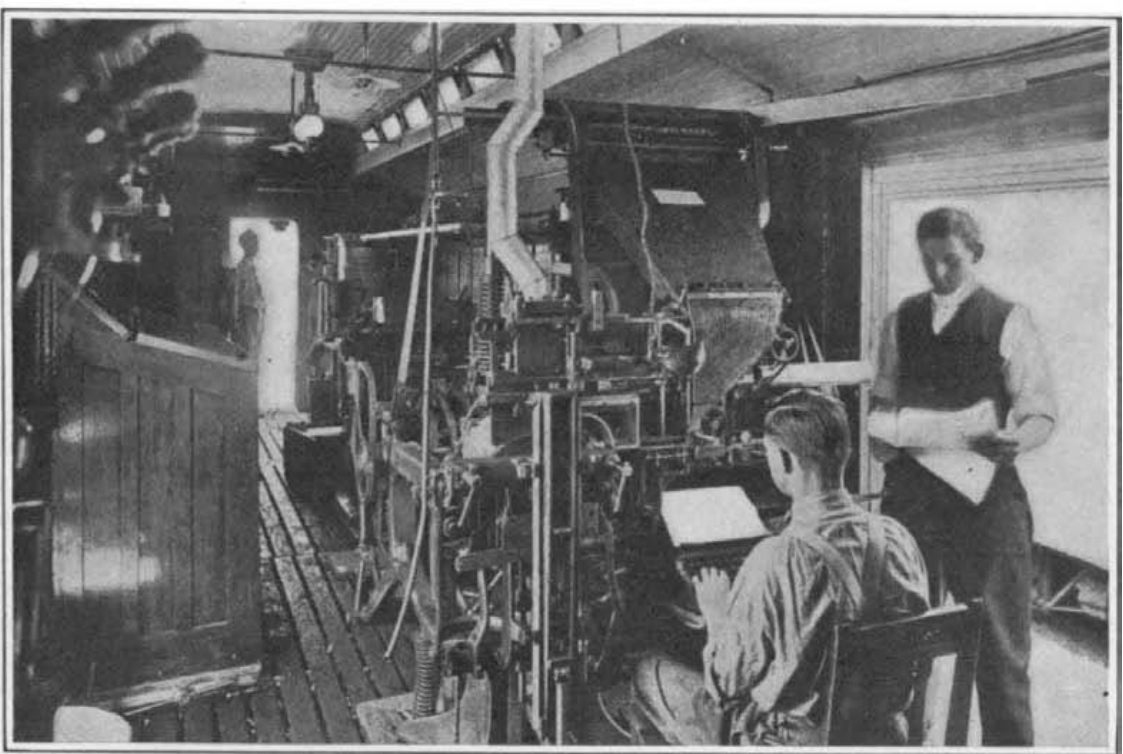

Composing room of the railway automobile newspaper plant.

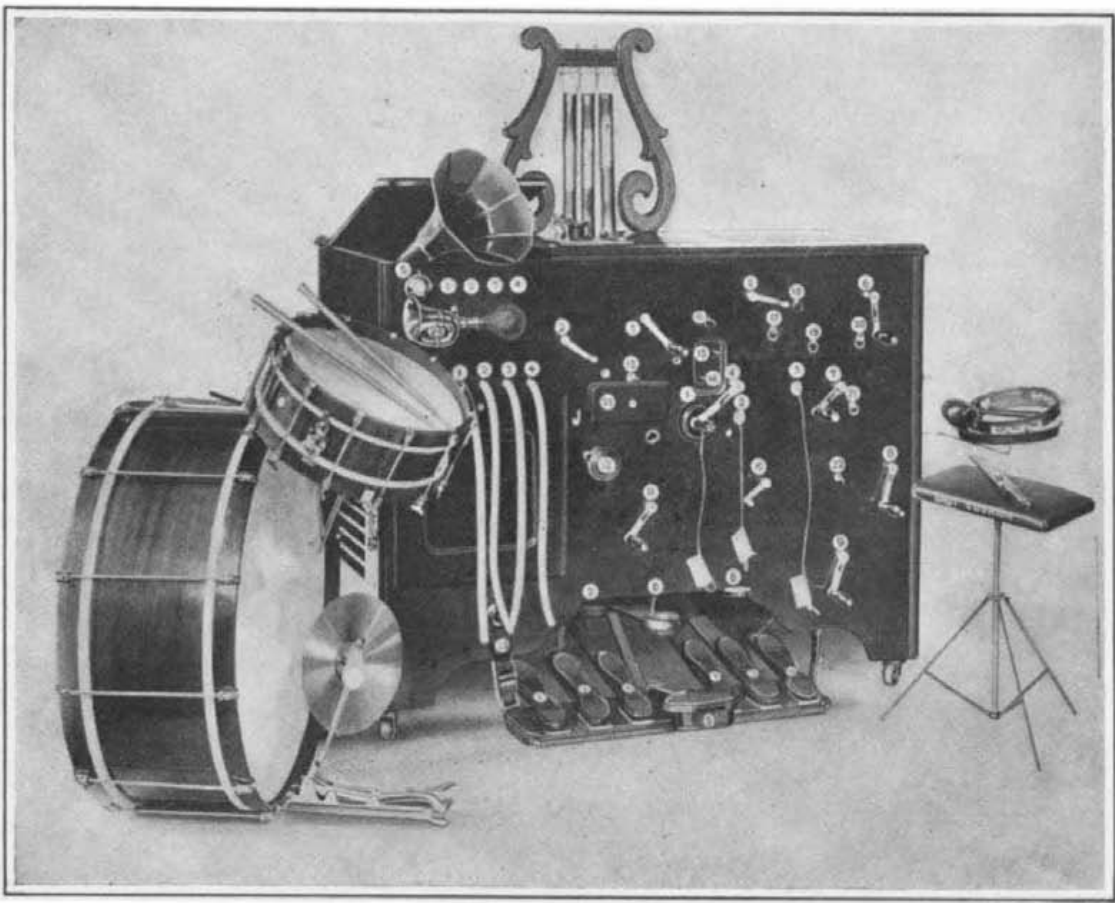

Noise orchestra for adding realism to moving picture exhibitions. different kinds of whistles ranging all the way from the speaking tube whistle to the cuckoo. There are fifteen different bell sounds, ranging from the patrol to the cash register. There are sounds in imitation of the surf, the splashing of water the rattle of musketry and artillery, the clatter of horses' hoofs over hard ground and over soft ground; thunderstorms wireless telegraphy; all sorts of machinery sounds, the chug of motor boats, the click of the typewriter, the raising of a latch, the blacksmith's anvil, the washing of dishes, everything in fact from the crash of breaking china to a kiss. In addition to these general noises that may be produced by the machine, it is equipped with musical attachments to produce church-organ music, cathedral chimes, violin music and that of brass instruments, either singly or in a band. The possibilities of this machine are apparently limitless, and should add greatly to the entertainment afforded by the moving picture exhibition.

\section{Egyptian Minerals}

A SIDE from its agriculture, attentio $A_{\text {is being directed to the mineral riche }}$ of Egypt, it being naturally asked whether valuable minerals are not to be found beneath the immense desert tracts extending beyond the Nile valley. A leading French authority Prof. Potier treating of this subject refers to the recent discovery of oil fields at Gemsah on the coast near the mouth of the Suez Gulf. One sounding operation traversed a 6-inch layer of ozokerite at a depth of $2 \overline{50}$ feet, and within the last few months the petroleum question is quite active. We may mention the first boat load of 6,000 tons of oil starting from the Red Sea and new petroleum fields have been lately discovered, it is stated, toward the Sinai region. Turning to copper production, Egypt wa rich in this metal in ancient times, but the mines were of such kind as to be easily worked and for this reason are now exhuusted. Traces of the copper mines have been found, in which the ore took the form of silicate and carbonate. However, a good vein of silicate is now found on the east cost of Sinai peninsula and other deposits are seen in neighboring places. Manganese deposits are also observed in this region, and good lead and zinc beds as well. Gold is already being taken out at several centers in the ex treme south of Egypt, and to the south of Assouan there have been lately takeı up the ancient gold mines of the period of the Ptolemies. On the shore of the Red Sea at Sukari quartz having three ounces per ton is now worked. Precious stones are represented by emerald, turquoise and peridot. Phosphates seem to be a more immediate and sure source of wealth for this country, and several beds in the Nile valley show 70 per cent of phosphates. The richest points, however, seem to be at Rachid in the Taklah oasis and at some distance out in the Libyan desert, 350 miles from the Nile valley, but the future extension of the railroad will bring these within reach.

\section{Dutch Dairy Methods}

$T^{\mathrm{HE}}$ most minute precautions are use $\boldsymbol{I}$ in the model dairy farms near the large centers in Holland in order to produce milk having the greatest degree of purity, it being designed specially for consumption as fresh milk. Even the kind of food given to the cows and its quality are loolsed after so as to avoid digestive troubles which are known to affect the quality of the milk. Before milking, the hind parts and udder are carefully washed with boiled water and boric acid, and the the animal is taken to the milking room this space being washed and disinfected once a day. The milk is collected in special sterilized buckets. In these establishments the personnel undergoes a medcal examination to insure their being quite healthy, and they are required to put on a special jacket before the milking, als to wash the hands in sterilized water. In this way the milk is assured to be as free from germs as it is possible to have it. 